\title{
PRICE SETTING IN TRANSITION: THE EFFECT OF TAKEOVER ON A PETROLEUM FIRM
}

\author{
Juraj Valachy \\ CERGE-EI*
}

ABSTRACT

\begin{abstract}
In this paper, I investigate the effect of the takeover of a Slovak petroleum firm on its price setting mechanism. In particular, I tested the changes in the reaction of output (fuel) price on input (dollar and crude oil) prices and competitors' prices (approximated by the reference Commodity Exchange fuel price). I find that during the time when the company was owned and controlled by managers, only negative changes in input prices were reflected in the output price. After the takeover of the firm by a foreign strategic investor, I identify a different price setting mechanism: the fuel price starts to react symmetrically to the input prices. The fuel price, however, reacts asymmetrically to the competitors' prices. In particular, the fuel price reacts to Brent increases and Gasoline decreases. Consecutive regression confirmed the hypothesis that before takeover the composite input costs and competitors' prices have very little (or no) impact on fuel price. After takeover, composite input costs as well as competitors' prices start to play an important role in price setting.
\end{abstract}

JEL classification: Q40, D21, L11, L71

Keywords: ownership structure, price setting, crude oil, ridge regression

ABSTRAKT

Cílem této práce je vyšetřit vliv převzetí Slovenské rafinérie na její cenový mechanizmus. Testuji změnu reakce ceny konečného produktu (benzínu) na ceny vstupních surovin (kurz dolaru a cena ropy) a konkurenčních výrobců (aproximované referenční cenou benzínu na komoditní burze). Ukazuje se, že pokud byla rafinérie vlastněna managementem, cena konečného výrobku reagovala jenom na pokles cen ropy. Po převzetí firmy zahraničním strategickým investorem můžeme identifikovat jiný cenový mechanizmus, kdy cena benzínu začíná reagovat symetricky na změny cen vstupních surovin. Cena benzínu však reagovala nesymetricky na změny cen konkurenčních prodejců. Cena benzínu reagovala zejména na zvýšení ceny ropy a snížení ceny benzínu kótovaného na burze. Následná regrese potvrdila hypotézu, že před převzetím firmy neměly celkové vstupní náklady a ceny konkurentů téměř žádný vliv na cenu benzínu. Po převzetí začaly celkové vstupní náklady i ceny konkurentů hrát důležitou roli při cenotvorbě.

*I would like to thank Evžen Kočenda for his comments, help and encouragement during my work. My thanks go also to Jan Kmenta for his advice. The usual disclaimer applies.

Correspondence to: Juraj Valachy, Center for Economic Research and Graduate Education and Economics Institute (CERGE-EI), P.O.Box 882, Politických vězňů 7, 11121 Prague, Czech Republic, tel. (420-2) 24005227, fax (420-2) 24227143, e-mail: juraj.valachy@cerge-ei.cz. 


\section{INTRODUCTION}

During the latest crisis in the crude oil market in 1999-2000, prices of crude oil reached levels of 35 USD per gallon. The weakening of the Euro against the U.S. dollar made the situation even worse. Prices of fuel rose to levels where the general public and political parties lost their patience and start to blame everyone and everything for the situation. Prices at gas stations became almost an integral part of the evening news all over Europe. All parts of the fuel production chain were condemned: OPEC countries for low production, refineries for asymmetric price reaction, governments for high taxes, and local gas stations for cartel behavior.

The general public in Slovakia claimed to observe an asymmetric relationship between fuel and oil prices - specifically that fuel prices respond when oil prices are rising but not when they are falling. The same holds for the response to the rise and the fall of the dollar. In this paper I want to test the symmetricity of these relationships and the price setting mechanism in general in the context of ownership change - from managerial to strategic foreign partner. However, this paper does not attempt to address how asymmetry might arise.

In particular, I want to examine the effect of the strategic foreign partner on the price setting mechanism of the Slovak petroleum company Slovnaft. I want to study the interactions between the input and output prices during two distinct periods. The first period was when the company was owned by the managers. The second period started when the company was taken over by the foreign strategic investor. Dividing the dataset into these two samples will allow me to identify changes in the price setting mechanism.

The asymmetric transmission of oil prices on fuel prices and the fuel market have been tested in Asplund, Eriksson and Friberg (2000) and Eltony (1998), among others. Bacon (1991) found asymmetry in the U.K. fuel market; Borenstein, Cameron and Gilbert 
(1997) found the same evidence for the U.S. market. Peltzman (2000) made a comprehensive study of price transmission using large samples of diverse products. $\mathrm{He}$ finds no asymmetry in the response of an individual decision maker (a supermarket chain) to its costs, but he finds above-average asymmetry where a cost shock is filtered through a fragmented wholesale distribution system.

None of these studies examined price transmission in the context of ownership. One of the few exemptions is Contin, Correlje and Huerta (1999). They examine the evolution of the Spanish gasoline market from the abolition of the state oil monopoly to "complete" liberalization.

In their papers, researchers determine the features of the transmission mechanism by using different econometric approaches. Cramon-Taubadel and Meyer (2000) offer a nice overview. The first approach, the oldest one, is based on Houck (1977) where he desegregates the price variables into increasing and decreasing phases. He was followed by Bailey and Brorsen (1989) and Mohanty, Peterson and Kruse (1995), among others. The second approach uses the asymmetric error correction model. This approach is motivated by the fact that the variables in the Houck specification are in differences and, therefore, they ignore the information that is reflected in their levels. Examples of these studies could be Engle and Granger (1987) or Granger and Lee (1989). The third approach is the threshold (or momentum) cointegration approach. This approach can be superior to earlier ones when the price series in question is cointegrated. Examples are Abdulai and Reider (1999) and Harper and Goodwin (1999).

An example of the second approach in the context of the fuel market could be Adrangi, Chatrath and Ripple (2001). They analyze the price dynamics of Alaska North Slope crude oil and Los Angeles diesel fuel prices. They employ VAR methodology and a bivariate GARCH model to show that there is strong evidence of a uni-directional causal 
relationship between the two prices. They conclude that the Alaska North Slope crude oil price is the driving force of changes in the Los Angeles diesel price. Borenstein, Cameron and Gilbert (1997) or Bake, Brown and Yucel (1996) use an error-correction model to model asymmetry, estimate variance decomposition, and the response function of a onetime shock in oil price.

The limitation of the second and third approaches is that they require sufficiently long data series to give reliable results. Bake, Brown and Yucel (1996), for example, use weekly data counting more than 1500 observations. My data set counts for only 114 observations, hence my decision regarding econometric approach is rather limited and the standard Houck approach is therefore my choice.

Cramon-Taubadel and Meyer (2000) points to the issue that can have a substantial impact on the identification of price asymmetry. They show that in the presence of a structural break in symmetrically - linked price data, it appears that the true size of tests for asymmetric price transmission is considerably larger than the chosen significance level. This implies that what appears to be asymmetric price transmission may in fact be due to other causes. Results reported later confirmed that the division of the sample into two parts has an impact on the results for price symmetricity. Therefore one has to take into account possible structural breaks, especially in transition countries.

For the purpose of my analyses I choose the Slovak petroleum firm Slovnaft. Slovnaft was transformed from a state company to a joint stock company in the course of the first wave of privatization. Since May $1^{\text {st }}$, 1992, all assets and liabilities of the state enterprise were transferred into the joint stock company together with one-third of the distribution network of fuels. The process of privatization was completed in several steps at the beginning of 1998. The majority stake was in the hands of the managerial joint stock company, Slovintegra; foreign investors held 33 percent of shares. Finally, Slovnaft, on 
March 31st, 2000, signed an agreement on a strategic partnership with MOL, one of the biggest Hungarian corporations.

Table 1 depicts the current shareholder structure in Slovnaft. The largest shareholder is Hungarian MOL with 36.22 percent, managers (represented by Slovintegra, a.s.) have 28.67 percent, the Bank of New York and the Fund of National Property each have around 8 percent and the remaining share $(18.74 \%)$ is in the hands of small investors and investment funds.

Slovnaft is the only big petroleum company in Slovakia. As such, it has a dominant position in the fuel market. The share of this single company in petroleum products retail is about 50 percent. The rest of the market is rather fragmented among other fuel suppliers, for example OMV or Transpetrol. Therefore, the prices of fuel at Slovnaft's gas stations are the ones which most influence the Slovakia fuel price level.

In this paper I look at the transmission mechanism in an ownership context from three different angles. The first method for examining the links among input and output prices is Granger causality. The second method is the calculation of the correlation matrix of all input and output price variables. These will show to what extent the prices of input factors tend to move with output prices. The last method is the estimation of regression equations, which identify sources of output price changes and examine the importance of these factors under different ownerships of companies. The specification will, at the same time, answer the dispute over the symmetricity of output price reaction to input prices.

There are many factors which should have an influence on output prices. Examples could be the direct input costs which are, in case of a petroleum company, the crude oil price (expressed in the U.S. dollar) or the dollar price (expressed in the local currency). Another example could be staff cost or tax rates. I decide to choose factors which are 
explicitly mentioned in official statements of the Slovnaft company. I have to stress that these factors differ during different ownership structures of the company.

The official statement of Slovnaft discusses the reasons for fuel price changes. At the same time it confirms the appropriateness of the division of the sample into two periods. Let me quote from a press release from before the takeover period:

We can reflect only legitimate costs into our prices. ...In our case besides the price of Crude oil as a global factor, also a local factor plays an important role - the exchange rate of the Slovak crown against the USD. We buy Russian crude oil for dollars. At the end of 1999, the price of crude oil significantly fell, but on the other hand the Slovak crown exhibited weakening against the dollar. (Slovnaft 2000a)

Clearly there are two reasons for fuel price increases: crude oil price and the Slovak crown. Shortly after the takeover, the reasoning for fuel price changes was a bit different: In accordance with the oil price development of Brent crude oil on the London Exchange, the listed prices of gasoline and motor oil on the Commodity Exchange and together with a weakening of the Slovak crown exchange rate against the USD, Slovnaft, a.s. has adjusted the retail price of motor fuels in own gas station network since September 9th, 2000. (Slovnaft 2000b)

We can see that besides crude oil price and the Slovak crown, there is a new additional factor — the price of gasoline on New York Commodity Exchange.

In order to distinguish the retail price of Slovnaft's fuel from the corresponding price on the Commodity Exchange, throughout the text I will refer to Slovnaft's fuel price by using just the word "fuel", and the corresponding fuel price quoted on Commodity Exchange by using the word "gasoline".

Let me devote a few lines to the gasoline price. The fact that there is a correlation of Slovnaft prices with other fuel prices may only mean that the prices are caused by the same things. This may only mean that Slovnaft is less efficient than other producers in incorporating raw material or other cost changes into prices. ${ }^{1}$ I have two reasons why I

\footnotetext{
${ }^{1}$ I would like to thank Prof. Filer for pointing out this issue.
} 
decide to include gasoline prices into the price analysis. The first one is that the price of fuel on the Commodity Exchange could be considered as the price of fuel at fuel stations other than Slovnaft. In Slovakia, other fuel sellers have no production capacities and have to import all products. Thus, the prices of Slovnaft's competitors could be concentrated into this variable. The second reason is that fuel's Commodity Exchange price is explicitly mentioned in Slovnaft's statements which describe the reasons for fuel price changes.

For the purposes of this paper I choose three different techniques: correlation matrix, Granger causality and running regressions. I find that during the time when a company was owned and controlled by managers only negative changes in input prices were reflected into the output price. Therefore, the increases in fuel price during that period have different reasons than the input price. After take-over, we have different results. One of the most important factors is the price of the U.S. dollar in terms of the Slovak crown, which reacts symmetrically. This is in line with the result of Asplund, Eriksson and Friberg (2000). They also find that the price of Swedish fuel responds more rapidly to the exchange rate than other factors, though the question of speed is not present in my analysis. Fuel price, however, reacts asymmetrically to the prices of gasoline. Namely, fuel reacts to Brent increases and gasoline decreases. However, I was not able to reject the $F$-test for the symetricity of the Brent reaction. The second regression specification confirmed the hypothesis that before takeover the composite input costs and the gasoline price have very little (or no) impact on the fuel price. After takeover, composite input costs as well as gasoline start to play import role in price setting. The Rsquared of the second specification (input factors are aggregated) is 0.44 while the decomposition of input factors (into their positive and negative parts) increased R-squared to 0.66 . 
The remainder of this article proceeds as follows. In the second section I present the methodology for testing the presence of Granger causality and the specification of regression equations. In section three I describe the data. Section four is devoted to empirical results. A brief conclusion is at the end.

\section{Methodology}

\subsection{Granger causality}

The interactions between input and output prices before and after takeover interest me. In particular, I intended to study the linkages between output price and factors which could influence it - crude oil, the dollar and gasoline price. The common way for studying interactions and linkages between variables is the well-known Granger causality. The intuition behind Granger causality is the following: Variable $X$ Granger-causes variable $Y$ if past values of $X$ help to predict the current value of $Y$.

Granger causality is defined as follows: Let $X_{t}, Y_{t}$ be two stationary time series with zero means. A simple causal model can be as follows:

$$
\begin{aligned}
& X_{t}=A(L) X_{t}+B(L) Y_{t}+\varepsilon_{t} \\
& Y_{t}=C(L) X_{t}+D(L) Y_{t}+\eta_{t},
\end{aligned}
$$

where $A(L), B(L), C(L)$, and $D(L)$ are power series in $L$, i.e. $A(L)=\sum_{j=1}^{m} a_{j} L^{j}$, etc. Variables $\varepsilon_{t}, \eta_{t}$ are taken to be two uncorrelated white-noise series, i.e. $E\left[\varepsilon_{t} \varepsilon_{s}\right]=0=$ $E\left[\eta_{\mathrm{t}} \eta_{\mathrm{s}}\right], s \neq t$, and $\mathrm{E}\left[\varepsilon_{\mathrm{t}} \varepsilon_{\mathrm{s}}\right]=0$ all $t, s$. The Granger definition of causality implies that $X_{t}$ causes $Y_{t}$ provided that $C(L) \neq 0$. Similarly, $Y_{t}$ causes $X_{t}$ if $B(L) \neq 0$.

Since the introduction of Granger causality in Granger (1969) there has been extensive research on the selection of lag length. There exist many lag-selection criteria, and, as Batten and Thornton (1985) claim, different lag selection criteria can result in 
different conclusions. In my paper I used the Hsiao (1981) two-stage procedure and Hannan-Quinn criterion suggested in Hannan \& Quinn (1979) and Quinn (1980).

\subsection{Regression specification}

In the introduction I mentioned reasons for sample division (before and after takeover) and potential factors for fuel price changes. Moreover, I put the question of symetricity in front. For the examination of all these issues I use two regression specifications. The first specification adopts the approach of Houck (1977) where the test for asymmetric price transmission is based on the segmentation of price variables into increasing and decreasing phases. Its purpose is to examine all sources of output price changes and the existence of symmetricity. On the other hand, the purpose of the second regression is, based on the results from the first, to assess the change in importance of total input cost and competitors' fuel price (represented by gasoline price) on Slovnaft pricing.

The first regression specification is the following:

$$
\begin{aligned}
\Delta F_{t}=\alpha+\beta_{1} \Delta O_{t-1}^{+}+\beta_{2} \Delta O_{t-1}^{-}+\gamma_{1} \Delta D_{t-1}^{+}+\gamma_{2} \Delta D_{t-1}^{-}+\delta_{1} \Delta G_{t-1}^{+}+\delta_{2} \Delta G_{t-1}^{-}+\varepsilon_{t} \\
\text { where } \Delta \mathrm{O}_{\mathrm{t}}^{+}=\max \left\{0, \Delta \mathrm{O}_{\mathrm{t}}\right\}, \Delta \mathrm{O}_{\mathrm{t}}^{-}=\Delta \mathrm{O}_{\mathrm{t}}^{+}-\Delta \mathrm{O}_{\mathrm{t}}, \\
\Delta \mathrm{D}_{\mathrm{t}}^{+}=\max \left\{0, \Delta \mathrm{D}_{\mathrm{t}}\right\}, \Delta \mathrm{D}_{\mathrm{t}}^{-}=\Delta \mathrm{D}_{\mathrm{t}}^{+}-\Delta \mathrm{D}_{\mathrm{t}}, \\
\Delta G_{t}^{+}=\max \left\{0, \Delta G_{t}\right\}, \Delta G_{t}^{-}=\Delta G_{t}^{+}-\Delta G_{t},
\end{aligned}
$$

$\Delta \mathrm{F}_{\mathrm{t}}$ is the change in the price of the fuel, $\Delta \mathrm{O}_{\mathrm{t}}$ is the change in Oil price, $\Delta \mathrm{D}_{\mathrm{t}}$ is the change in the price of the dollar, and $\Delta G_{t}$ is the change in the price of gasoline on the Commodity Exchange. By changes I mean the first logarithmic differences of variables in their level values, e.g. $\Delta F_{t}=\ln \left(F_{t}\right)-\ln \left(F_{t-1}\right)$. This transformation will also ensure the stationarity of the series and, at the same time, is a very close approximation of the growth rates. 
This specification has three advantages. First, it will enable me to filter out the effect of a one-time price change not caused by the Slovnaft company. Such an event can be, for example, a change in the consumption tax on fuel. Second, the estimated coefficients will be the fuel price elasticities with respect to the particular input price. In other words, a one-percent increase in the price of the dollar in terms of the Slovak crown should cause a $\gamma_{1}$ percent increase in fuel price. The third advantage lies in the separation of the positive changes from negative ones. This separation will allow me to test for symmetricity of coefficients, namely whether a one percent increase in input price has the same effect on output price as a one percent drop. Formally, I will test these hypotheses:

$$
\begin{aligned}
& H_{0}: \beta_{1}+\beta_{2}=0<H_{0}^{\prime}: \beta_{1}+\beta_{2} \neq 0 \text { for the oil price changes, } \\
& H_{1}: \gamma_{1}+\gamma_{2}=0<>H_{1}^{\prime}: \gamma_{1}+\gamma_{2} \neq 0 \quad \text { for the dollar price changes, }
\end{aligned}
$$

and $H_{2}: \delta_{1}+\delta_{2}=0<>H_{2}: \delta_{1}+\delta_{2} \neq 0 \quad$ for the gasoline price changes.

The second specification determines the importance of the total input costs and gasoline price on fuel price changes, again in an ownership context. Basically, I put on one side the input material cost (Brent and dollar price) and competitors' fuel price (gasoline) on the other side and try to find out which one is more important for Slovnaft's price decision making. The regression is as follows:

$$
\Delta F_{t}=\alpha_{1}+\alpha_{2} T O_{t}+\beta_{1} \Delta \text { TIC }_{t-1}^{1}+\beta_{2} \Delta T I C_{t-1}^{2}+\delta_{1} \Delta \text { Gasoline }_{t-1}^{1}+\delta_{2} \Delta \text { Gasoline }_{t-1}^{2}+\varepsilon_{t}
$$

where $T I C_{t}^{1}=F_{t} * D_{t}$ if time $<$ time of takeover, 0 otherwise;

$T I C_{t}^{2}=F_{t} * D_{t}$ if time $>$ time of takeover, 0 otherwise;

$\Delta \mathrm{F}_{\mathrm{t}}$ is the change in the price of fuel; and $\Delta G_{t}$ is the change in the price of gasoline on the Commodity Exchange. TO is a dummy variable which has a value 1 after takeover and 0 otherwise. The TIC variable represents total input costs and is defined as the price of 
one gallon of Brent crude oil expressed in Slovak crowns. ${ }^{2}$ Because of same reasons stated above, by changes I mean the first logarithmic differences.

Using the price of Brent and its derivative product-gasoline-causes a multicollinearity problem. A possible way to overcome the multicollinearity in the independent variables is ridge regression. A ridge estimator of the coefficients in a linear model has the form

$$
b_{r}=\left(X^{\prime} X+\gamma I\right)^{-1} X^{\prime} y
$$

where $I$ is the identity matrix of the order of the number of independent regressors and $\gamma$ is a positive scalar computed as suggested in Sclove (1973) and described in Amemiya (1985). This positive constant $\gamma$ should reduce the tendency of $X^{\prime} X$ to be singular or nearly singular.

\section{EMPIRICAL RESULTS}

The choice of all data sources is based on the commentaries of the Slovnaft company, where they refer to all factors of fuel price changes and their sources. I downloaded the prices of Slovnaft's fuel from the Slovnaft web site. As a reference fuel price I take the unleaded Natural 95, which is the most common type of fuel used by drivers. Since Slovnaft pays Russian crude oil prices that are fully derived from the prices of crude oil on the London exchange, I downloaded the prices of crude oil from the web site of IPE London and considered them as the prices which Slovnaft paid to Russian oil companies.

\footnotetext{
${ }^{2}$ Naturally, the definition of total input costs should involve not only material costs (as I am doing), but also labour cost, investments and other costs. In my paper the time span is about two and a half years. This is quite a short period and the frequency of changes is between one and two weeks. Labour costs, for example, are usually set one year ahead. Therefore a jump in labour costs once in a year could have an impact on fuel price but this outlier would not influence regression results.
} 
The price of gasoline was downloaded from the webpage of New York Commodity Exchange. These data sources are based on the commentaries of Slovnaft, where they refer to this particular institution. Another source could be the Commodity Exchange in Rotterdam. Both Rotterdam and New York exhibit high correlation, so the location of the Commodity Exchange should not play an important role. Prices of the U.S. dollar in terms of the Slovak crown were downloaded from the web site of National Bank of Slovakia.

My sample starts in January 1999 when Slovnaft for the first time published its prices on the Internet. The sample ends in August 2001. During this period Slovnaft irregularly changed its prices. The average number of days between two price changes is before the takeover period 11.3 (st. dev. 10.02), and after takeover 6.9 (st. dev. 0.86). During the before-takeover period $83 \%$ of the price changes occurred on Tuesday or Wednesday and during the after-takeover period $90 \%$ of changes occurred on Tuesday. All other variables are in daily frequencies. Therefore I calculated the average of the daily values of these variables for the periods when the price of fuel did not change. Finally, I ended up with a sample whose frequency was the same as the fuel price changes.

The evolution of fuel and gasoline prices is depicted in figure 1. Figure 2 shows the evolution of composite input costs - the cost of 1 barrel of crude oil in terms of the Slovak crown - and the price of Slovnaft's fuel in terms of Slovak crowns. From both figures we can see that the fuel price closely traces the input and/or gasoline prices (with one lag). Table $2 \mathrm{a}$ shows the basic statistics of growth rates of the above-mentioned time series (average, standard deviation, minimum and maximum value). Table $2 \mathrm{~b}$ summarizes cumulative changes in respective variables. 


\subsection{Correlation matrices}

The correlation matrix of input and output prices and their lagged values is in table 3 . This matrix indicates the extent to which these variables tend to move together. The correlation coefficients are reported similarly to Kočenda (2001). The coefficients are reported for before as well as for after the takeover period to contrast the differences in their values. The left portion of table contains coefficients for before-takeover period, while the upper right portion contains the coefficients for after-takeover period.

In general, the correlation coefficients of the current value of fuel and the lagged value of the input price for before the takeover period are around 0 , only some values reach 0.3 . These low values can be interpreted as a low connection between input and output price.

Correlation coefficients for the after-takeover period are on average higher then those before takeover. This can be interpreted as the emergence of the missing connections between lagged input and current output prices.

\subsection{Granger causality}

For testing Granger causality I use the specification in equation (1). Variables $X_{t}$ and $Y_{t}$ are first logarithmic differences of the examined time series.

Table 4.1 depicts the estimated causality links among the price of fuel, the dollar and Brent for the before-takeover period. ${ }^{3}$ One can see that there are no links from input to output prices. Contrary to expectations, there is just one link which runs from fuel to dollar price. This spurious result means that the fuel price helps to predict the dollar price. It is important that there are no links running from the dollar or Brent to the fuel price. I can

\footnotetext{
${ }^{3}$ According to the official statement gasoline price should not play any role during the before-takeover period. Regression results which are reported later confirmed this fact. This is the reason I did not include gasoline price into the analyses of this period.
} 
conclude that before takeover the prices of fuel did not reflect the price of the dollar or Brent. This finding is contrary to Slovnaft press releases.

Table 4.2 is calculated for the period after the takeover. The company, according to press releases, started to include the price of gasoline on the Commodity Exchange into the price setting mechanism. This is why I also include gasoline into the group of variables under examination. The results showed the emerged links which run from the dollar and Brent price to the fuel price. Moreover, there are no additional (spurious) linkages as in the case of the before-takeover period. To conclude, using Granger causality I can claim that the takeover has provided the missing links in the development of the output price.

\subsection{Regression}

I estimated equation (2) for three samples: The first sample is the whole period with 114 observations, the second sample covers the period before takeover (39 observations), and the third sample covers period after takeover (75 observations). The results from the OLS regression and $F$-tests are presented in table 5. The number of lags of independent variables is made on a rule of thumb, namely, I start with one lag and some coefficients were significant. Then I increase the number of lags to two and I find out that none of the coefficients is significant for any of the three samples. The same situation remains when I include the current values of independent variables into the equation.

Using the price of Brent and gasoline in the same regression as the explanatory variables could cause a multicollinearity problem. Indeed, the correlation of these two variables is 0.535 , which is high enough to investigate this potential effect. However, the decomposition of these two variables into their positive and negative parts will decrease the correlation of the resulting four variables to values of around 0.37 . This number should 
be low enough to ensure that the standard errors of estimated coefficients would not be excessively high.

From table 5 we can see that during the whole period only the negative changes in input costs (dollar and Brent) are reflected in the changes of the output price (fuel). The same holds for the reaction of fuel to gasoline prices. In other words, increases in fuel prices were not caused by increases in the dollar, Brent or gasoline prices. This is an interesting result that can be attributed to different price setting under different ownership.

The division of the sample into before and after takeover sheds light on the changes in the price-setting mechanism. Estimations for the sample covering the beforetakeover period only confirmed the results obtained for the whole period — only negative changes in input prices are reflected in output prices. Despite the fact that official statements from Slovnaft did not claim gasoline price as a factor influencing fuel price, I include this variable into the explanatory variables. This variable shows to be insignificant. Hence, increases in fuel price were not the result of increased input prices. The R squared of 0.3 confirmed that the price setting mechanism was not based on input prices.

The results for the after-takeover period are interesting. The price of fuel starts to symmetrically react to the dollar price. A corresponding $F$-test did not reject the hypotheses of the equality of the coefficient of the positive and negative parts of the dollar price variable. Therefore, I can claim that fuel symmetrically reacts to the dollar. The elasticity is less than unity, in other words a 1 percent increase in the dollar price would not cause a 1 percent increase in the fuel price (rather, 0.375 percent).

The reaction of the fuel price to the Brent price is rather different from before takeover. An increase in the Brent price is reflected in the fuel price, whereas a decrease is not. In other words, Slovnaft increases the fuel price when Brent rises, but does not decrease when Brent falls. This behavior is in line with the public perception of the 
asymmetric reaction of Slovnaft to the prices of Brent. However, a corresponding $F$-test was not able to reject hypotheses of symetricity.

The third factor which, according to the above-mentioned Slovnaft statements, should have influence on fuel price is the gasoline price on the Commodity Exchange. The regression results confirmed this statement but only partially. Only negative price changes in gasoline have an influence on fuel. Increases in world prices of gasoline have no effect on Slovnaft fuel. Using an $F$-test I was able to reject hypotheses of symetricity.

My last comment is that changes in input prices do not fully describe the behavior of the output price. The R squared is 0.65 , which suggests that the price of fuel is also determined by other factors than input prices or in a different way than my specification (not linearly).

Let me speculate a bit about the reasons for this price behavior. The company operates on large share of the Slovak fuel market. According to the Annual Report 2000, this share reached almost $50 \%$. Though this number is high, there is still residual demand high enough that in case of significant decreases in world fuel prices, other companies would import this cheap fuel. Such a situation would mean a loss of market for Slovnaft, therefore Slovnaft has to react to decreases in world fuel prices.

On the other hand, Slovnaft does not react to increases in world fuel prices. Other companies which sell fuel on the Slovak market has to import all their quantity, so their prices will reflect the world market to a larger extent than Slovnaft does. In the case of an increase of world fuel prices, these companies are forced to increase their prices as well. Slovnaft can gain additional market share by not increasing its own prices. This is, however, only a hypothesis, which cannot be confirmed or rejected. 
Table 6 presents results from the estimation of the regression equation (3). Despite the multicollinearity problem, the results seem to be in line with expectations. The correlation of total input cost and the gasoline variable is around 0.8 , which is quite high. Therefore I employ the ridge regression method. Both of these methods (OLS and ridge regression) produce similar results. Before takeover, the total input cost has a very small influence on the fuel price, whereas gasoline has none. On the other hand, after takeover, the total input cost and gasoline are significant variables in fuel price determination. The $\mathrm{R}$ squared is 0.4 , which suggests there is more in the fuel price evolution than input prices.

\section{CONCLUSION}

Using a correlation matrix, Granger causality and running regressions I examined the links between the fuel price on the one side and the dollar, Brent crude oil and gasoline prices on the other side. I find that during the time when Slovnaft was owned and controlled by managers, only negative changes in input prices were reflected in the output price. Therefore, the increases in fuel price during that period have different reasons than the input price. From figure 2 we can see a gap between fuel prices and their composite input costs. This gap was widening prior to takeover, leaving space for lowering fuel prices after takeover. And actually, after takeover, we can identify different factors influencing the fuel price. As one of the most important factors I identify the price of the dollar in terms of the Slovak crown. The reaction of fuel to dollar changes is symmetric. The fuel price, however, reacts asymmetrically to the price of gasoline. In particular, fuel reacts to Brent increases and gasoline decreases. Moreover, the gap between input costs and the output price became lower than before. An R squared of 0.65 suggests that there is more behind 
the fuel price evolution and further research is needed. Consecutive regression confirmed the hypothesis that before takeover the composite input costs have very little (or no) impact on fuel. After takeover, composite input costs as well as the Commodity Exchange fuel price (as an indicator of competitors' prices) start to play an important role in price setting. Again, an $\mathrm{R}$ squared of 0.44 calls for further research. At the same time, examining the effects of takeovers of other petroleum factories (for example Polish POL) could bring interesting results. 


\section{REFERENCES}

Abdulai, A. and P. Rieder, 1999, "Using threshold cointegration to estimate asymmetric price transmission in the Swiss pork market", Working Paper ETH, Zürich.

Adrangi B, Chatrath A, Raffiee K, and R.D. Ripple, 2001, “Alaska North Slope crude oil price and the behavior of diesel prices in California", Energy Economics 23: (1) 29-42, Jan 2001.

Amemiya, Takeshi, Advanced Econometrics, Harvard University Press, Cambrige, Mass., 1985.

Asplund, M., Eriksson, R., Friberg, R, 2000, "Price adjustments by a gasoline retail chain", Scandinavian Journal of Economics 102 (1): 101-121.

Bacon, Robert W., 1991, "Rockets and feathers: The asymmetric speed of adjustment of U.K. retail gasoline prices to cost changes”, Energy Economics 13 (July): 211-18.

Bailey, D. and B.W. Brorsen, 1989, "Price asymmetry in spatial fed cattle markets", Western Journal of Agricultural Economics 14: 246- 252.

Bake, Brown and Yucel, 1996, "Crude oil and fuel prices: An asymmetric relationship? Economic Review", Federal Reserve Bank of Dallas, First Quarter 1996.

Batten, Dallas S., and Daniel L. Thornon, 1983, "Lag-length selection criteria: Empirical results from the St. Louis equation", Federal Reserve Bank of St. Louis Research paper 83 .

Borenstein, S., Cameron, and A.C., Gilbert, 1997, "Do gasoline prices respond asymmetrically to crude oil price changes?", Quarterly Journal of Economics 112 (1), Feb 1997.

Contin I, A. Correlje, and E. Huerta, 1999, “The Spanish gasoline market: From ceiling regulation to open market pricing", Energy Journal 20 (4): 1-14.

Cramon-Taubadel, S. von and J. Meyer, 2000, “Asymmetric price transmission: Fact or artefact?", Diskussionsbeitrag 0002, Institut für Agrarökonomie, Göttingen.

Eltony, M. N., 1998, "The asymmetry of gasoline prices: Fresh evidence from an error correction model for UK and USA", International Journal of Energy Research 22(3): 271-276, March 1998.

Engle, R.F. and C.W.J. Granger, 1987, "Cointegration and error correction: Representation, estimation and testing”, Econometrica 49: 251- 276.

Hannan, E.J. and Quinn, 1979, "The determination of the order of an autoregression", Journal of Royal Statistical Society B41: 190-195. 
Harper, D.C. and B.K. Goodwin, 1999, "Price transmission, threshold behavior, and asymmetric adjustment in the U.S. pork sector", Paper presented at the 1999 AAEA Meetings in Nashville, May 14, 1999.

Houck, P.J., 1977, “An approach to specifying and estimating nonreversible functions”, American Journal of Agricultural Economics 59: 570- 572.

Hsiao, Cheng., 1981, "Autoregressive modelling and money-income causality detection", Journal of Monetary Economics 7: 85-106, January 1981.

Granger C. W. J., 1969, "Investigating causal relations by econometric models and crossspectral methods", Econometrica 37(3): 424-38, July 1969.

Granger, C.W.J. and T. - H. Lee, 1989, "Investigation of production, sales and inventory relationships using multicointegration and non- symmetric error correction models", Journal of Applied Econometrics 4: 145- 159.

Kočenda, E., 2001, "Macroeconomic convergence in transition countries", Journal of Comparative Economies 29: 1-23.

Kočenda E., 1998, Exchange Rate in Transition, CERGE Charles University, ISBN 8086286-08-8.

Mohanty, S., Peterson, E.W.F. and N.C. Kruse, 1995, "Price asymmetry in the international wheat market", Canadian Journal of Agricultural Economics 43: 355 366.

National Bank of Slovakia, www.nbs.sk, accessed in May 2001.

Quinn, B.G., 1980, “Order determination for a multivariate autoregression”, Journal of Royal Statistical Society B42: 182-185.

Peltzman, S, 2000, "Prices rise faster than they fall", Journal of Political Economy 108 (3), June 2000.

Sclove, S.L., "Least squares problem with random regression coefficients", Technical Report No.87, IMSSS, Stanford University, 1973.

Slovnaft, 2000a, "Kto hýbe cenou motorových palív [Who moves with fuel prices]", Slovnaft official statement, http://www.slovnaft.sk/, accessed in May 2001, March 30. 2000.

Slovnaft, 2000b, “Zvýšenie cien motorových palív [Increase in prices of fuel]”, Slovnaft official statement, www.slovnaft.sk, accessed in May 2001, September 5, 2000. 
TABLE 1

Shareholder structure of Slovnaft to May 31, 2000.

Shareholder

STAKE \%

MOL Hungarian Oil and Gas Public Ltd

36.22

Slovintegra, a. s.

28.67

The Bank of New York

8.39

Fund of National Property

7.98

Other Investment funds and shareholders

18.74

TABLE 2A

Summary statistics for the examined time series.

\begin{tabular}{lccrrc}
\hline \hline & $\begin{array}{c}\text { Num. of } \\
\text { Obs. }\end{array}$ & Mean & Std. Dev. & Min & Max \\
\hline \hline Changes in Dollar (whole period) & 114 & 0.002 & 0.016 & -0.043 & 0.065 \\
Changes in Dollar (before takeover) & 39 & 0.004 & 0.019 & -0.043 & 0.065 \\
Changes in Dollar (after takeover) & 74 & 0.001 & 0.014 & -0.030 & 0.033 \\
\hline Changes in Fuel (whole period) & 114 & 0.003 & 0.020 & -0.064 & 0.075 \\
Changes in Fuel (before takeover) & 39 & 0.009 & 0.020 & -0.038 & 0.075 \\
Changes in Fuel (after takeover) & 74 & -0.001 & 0.019 & -0.064 & 0.031 \\
\hline Changes in Brent (whole period) & 114 & 0.007 & 0.038 & -0.094 & 0.216 \\
Changes in Brent (before takeover) & 39 & 0.020 & 0.044 & -0.048 & 0.216 \\
Changes in Brent (after takeover) & 74 & 0.001 & 0.033 & -0.094 & 0.071 \\
\hline Changes in Gasoline (whole period) & 114 & 0.007 & 0.060 & -0.151 & 0.291 \\
Changes in Gasoline (before takeover) & 39 & 0.024 & 0.058 & -0.060 & 0.291 \\
Changes in Gasoline (after takeover) & 74 & -0.001 & 0.059 & -0.151 & 0.131 \\
\hline \hline
\end{tabular}

TABLE 2B

Cumulative change in the price of fuel, the dollar, Brent and gasoline price: whole period, before and after takeover

\begin{tabular}{lccc}
\hline \hline & $\begin{array}{c}\text { Whole } \\
\text { Period }\end{array}$ & $\begin{array}{c}\text { Before } \\
\text { Takeover }\end{array}$ & $\begin{array}{c}\text { After } \\
\text { Takeover }\end{array}$ \\
\hline \hline Changes in Fuel & 0.294 & 0.374 & -0.080 \\
Changes in Dollar & 0.263 & 0.167 & 0.096 \\
Changes in Brent & 0.841 & 0.781 & 0.060 \\
Changes in Gasoline & 0.846 & 0.943 & -0.097 \\
\hline \hline
\end{tabular}


TABLE 3

Correlations of daily changes (and their lagged values):

price of fuel, the dollar, Brent crude oil, and gasoline

\begin{tabular}{|r|c|c|c|c|c|c|c|c|}
\hline & $\begin{array}{c}\text { Change } \\
\text { in fuel }\end{array}$ & $\begin{array}{c}\text { Lagged } \\
\text { change } \\
\text { in fuel }\end{array}$ & $\begin{array}{c}\text { Change } \\
\text { in dollar }\end{array}$ & $\begin{array}{c}\text { Lagged } \\
\text { change in } \\
\text { dollar }\end{array}$ & $\begin{array}{c}\text { Change } \\
\text { in Brent }\end{array}$ & $\begin{array}{c}\text { Lagged } \\
\text { change } \\
\text { in Brent }\end{array}$ & $\begin{array}{c}\text { Change in } \\
\text { Gasoline }\end{array}$ & $\begin{array}{c}\text { Lhange in } \\
\text { Gasoline }\end{array}$ \\
\hline Change in fuel & 1 & 0.392 & 0.222 & 0.454 & 0.199 & 0.595 & 0.188 & 0.661 \\
\hline Lagged change in fuel & -0.159 & 1 & 0.027 & 0.228 & 0.190 & 0.207 & 0.035 & 0.190 \\
\hline Change in dollar & -0.089 & -0.343 & 1 & 0.365 & 0.225 & 0.242 & 0.135 & 0.118 \\
\hline Lagged change in dollar & 0.253 & -0.112 & 0.312 & 1 & -0.002 & 0.216 & -0.158 & 0.136 \\
\hline Change in Brent & -0.044 & 0.048 & 0.425 & 0.366 & 1 & 0.304 & 0.535 & 0.216 \\
\hline Lagged change in Brent & 0.160 & -0.060 & 0.012 & 0.386 & 0.028 & 1 & 0.097 & 0.528 \\
\hline Change in Gasoline & & & & & & & 1 & 0.197 \\
\hline Lagged change in Gasoline & & & & & & & & 1 \\
\hline
\end{tabular}

Note: I use a notation similar to Kočenda (2001). The table's lower left portion contains correlation coefficients for before the takeover period; the upper right portion contains coefficients for after the takeover period.

TABLE 4.1-4.2

Granger causality: price of fuel, the dollar, Brent and gasoline.

Time span: before and after takeover .

TABLE 4.1 Before takeover

\begin{tabular}{|l|l|l|l|}
\hline & Fuel & Dollar & Brent \\
\hline Fuel & & $\rightarrow^{\mathrm{B}}$ & \\
\hline Dollar & & & \\
\hline Brent & & & \\
\hline
\end{tabular}

TABLE 4.2 After takeover

\begin{tabular}{|l|l|l|l|l|}
\hline & Fuel & Dollar & Brent & Gasoline \\
\hline Fuel & & & & \\
\hline Dollar & $\rightarrow^{\mathrm{A}}$ & & & \\
\hline Brent & $\rightarrow^{\mathrm{A}}$ & & & \\
\hline Gasoline & & & & \\
\hline
\end{tabular}

Note: I use a notation similar to Kočenda (1998). A and B denote significance at the $1 \%$ level, and the $5 \%$ level, respectively. 
TABLE 5

Regression of changes of fuel on changes in the dollar and Brent

\begin{tabular}{|c|c|c|c|}
\hline & \multicolumn{3}{|c|}{ Change in fuel price } \\
\hline & $\begin{array}{l}\text { Whole } \\
\text { period }\end{array}$ & $\begin{array}{l}\text { Before take- } \\
\text { over }\end{array}$ & $\begin{array}{c}\text { After take- } \\
\text { over }\end{array}$ \\
\hline 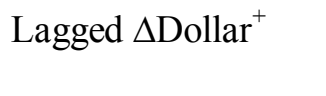 & $\begin{array}{l}0.072 \\
(0.165)\end{array}$ & $\begin{array}{r}-0.121 \\
(0.172)\end{array}$ & $\begin{array}{l}0.375 \mathrm{~B} \\
(0.167)\end{array}$ \\
\hline Lagged $\Delta$ Dollar & $\begin{array}{c}-0.665 \mathrm{~A} \\
(0.172)\end{array}$ & $\begin{array}{c}-0.867 \mathrm{~B} \\
(0.359)\end{array}$ & $\begin{array}{c}-0.471 \mathrm{~B} \\
(0.205)\end{array}$ \\
\hline Lagged $\Delta$ Brent $^{+}$ & $\begin{array}{l}0.053 \\
(0.065)\end{array}$ & $\begin{array}{r}-0.072 \\
(0.123)\end{array}$ & $\begin{array}{l}0.244 \mathrm{~A} \\
(0.084)\end{array}$ \\
\hline Lagged $\Delta$ Brent & $\begin{array}{c}-0.214 \mathrm{~A} \\
(0.08)\end{array}$ & $\begin{array}{c}-0.961 \mathrm{~A} \\
(0.253)\end{array}$ & $\begin{array}{r}-0.082 \\
(0.075)\end{array}$ \\
\hline 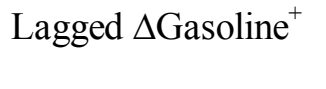 & $\begin{array}{r}-0.012 \\
(0.047)\end{array}$ & $\begin{array}{l}0.044 \\
(0.096)\end{array}$ & $\begin{array}{l}0.055 \\
(0.051)\end{array}$ \\
\hline Lagged $\Delta$ Gasoline ${ }^{-}$ & $\begin{array}{c}-0.234^{\mathrm{A}} \\
(0.038)\end{array}$ & $\begin{array}{l}0.230 \\
(0.181)\end{array}$ & $\begin{array}{c}-0.217 \mathrm{~A} \\
(0.037)\end{array}$ \\
\hline Constant & 0.011 & 0.0175 & 0.0006 \\
\hline Hypothesis $\mathrm{H}_{0}$ & $4.31^{* *}$ & $4.86^{* *}$ & 0.09 \\
\hline Hypothesis $\mathrm{H}_{1}$ & 2.19 & $10.32^{* * *}$ & 1.88 \\
\hline Hypothesis $\mathrm{H}_{2}$ & $14.62^{* * *}$ & 1.57 & 5.57 \\
\hline R-square & 0.468 & 0.324 & 0.656 \\
\hline $\begin{array}{l}\text { Num.of Obs. } \\
\text { Note: Standard errors are }\end{array}$ & $\begin{array}{r}114 \\
\text { enthesis }\end{array}$ & 39 & 75 \\
\hline
\end{tabular}

TABLE 6

Regression of changes in fuel price on changes in Total Input Costs and Gasoline prices

\begin{tabular}{lcc}
\hline & \multicolumn{2}{c}{ Change in fuel price } \\
\cline { 2 - 3 } & $\begin{array}{c}\text { Ridge } \\
\text { Regression }\end{array}$ & $\begin{array}{c}\text { Robust } \\
\text { OLS }\end{array}$ \\
\hline \hline Lagged $\Delta$ TIC 1 & $0.170^{\mathrm{C}}$ & $0.170^{\mathrm{B}}$ \\
& $(0.094)$ & $(0.085)$ \\
Lagged $\Delta$ TIC 2 & $0.221^{\mathrm{A}}$ & $0.221^{\mathrm{A}}$ \\
& $(0.040)$ & $(0.053)$ \\
Lagged $\Delta$ Gasoline 1 & -0.7099 & -0.099 \\
& $(0.081)$ & $(0.079)$ \\
Lagged $\Delta$ Gasoline 2 & $0.136^{\mathrm{A}}$ & $0.136^{\mathrm{A}}$ \\
& $(0.027)^{\mathrm{B}}$ & $(0.034)$ \\
Takeover Dummy & $-0.009^{\mathrm{B}}$ & $-0.009^{\mathrm{A}}$ \\
& $(0.004)$ & $(0.003)$ \\
Constant & $0.008^{\mathrm{B}}$ & $0.008^{\mathrm{A}}$ \\
& $(0.004)$ & $(0.003)$ \\
\hline R-square & 0.415 & 0.439 \\
Number of Obs. & 114 & 114 \\
\hline \hline
\end{tabular}

Note: Standard errors are in parentheses. $A, B$, and $C$ denote significance at the $1 \%, 5 \%$ and $10 \%$ level, respectively. TIC stands for Total Input Costs. 
FIGURE 1

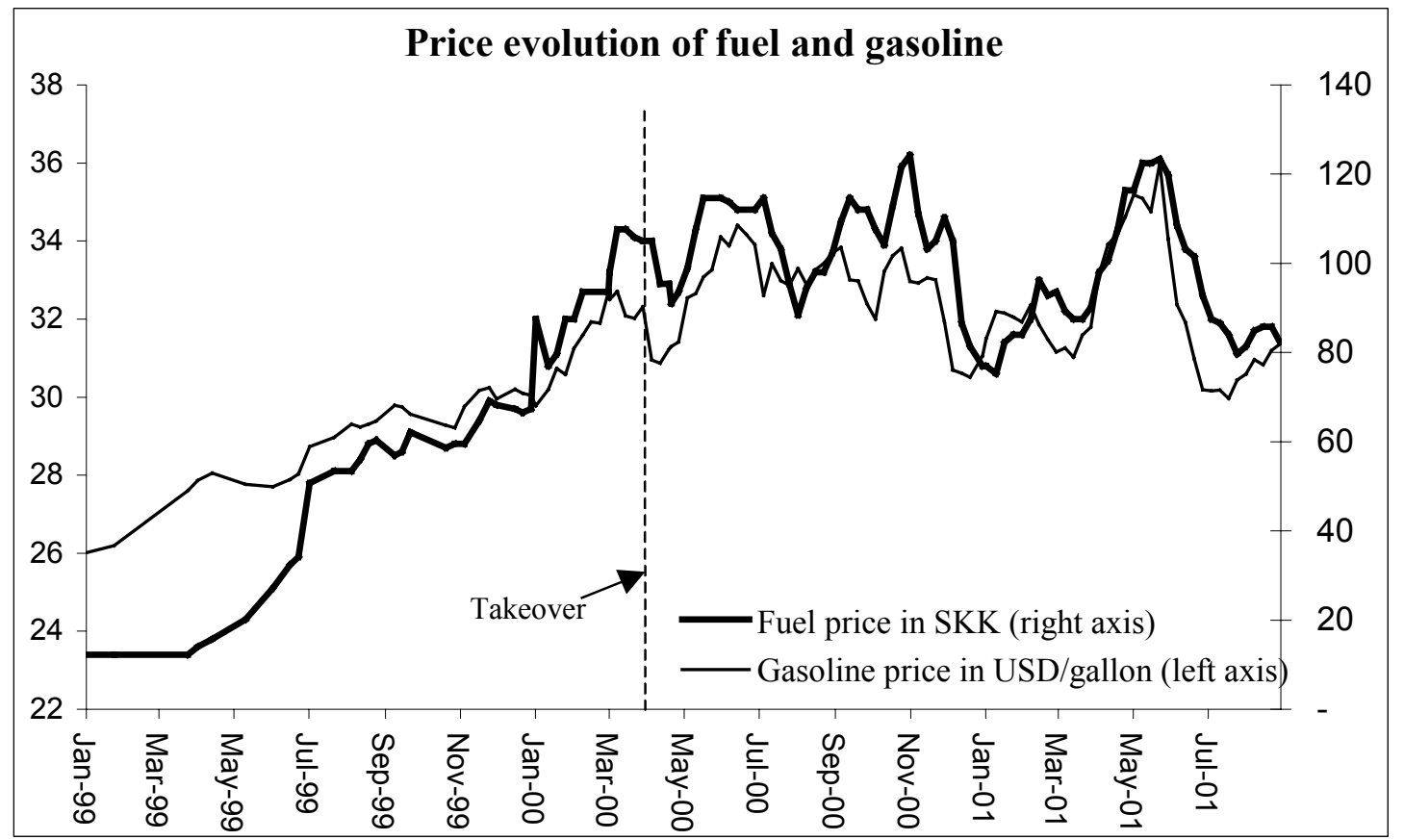

FIGURE 2

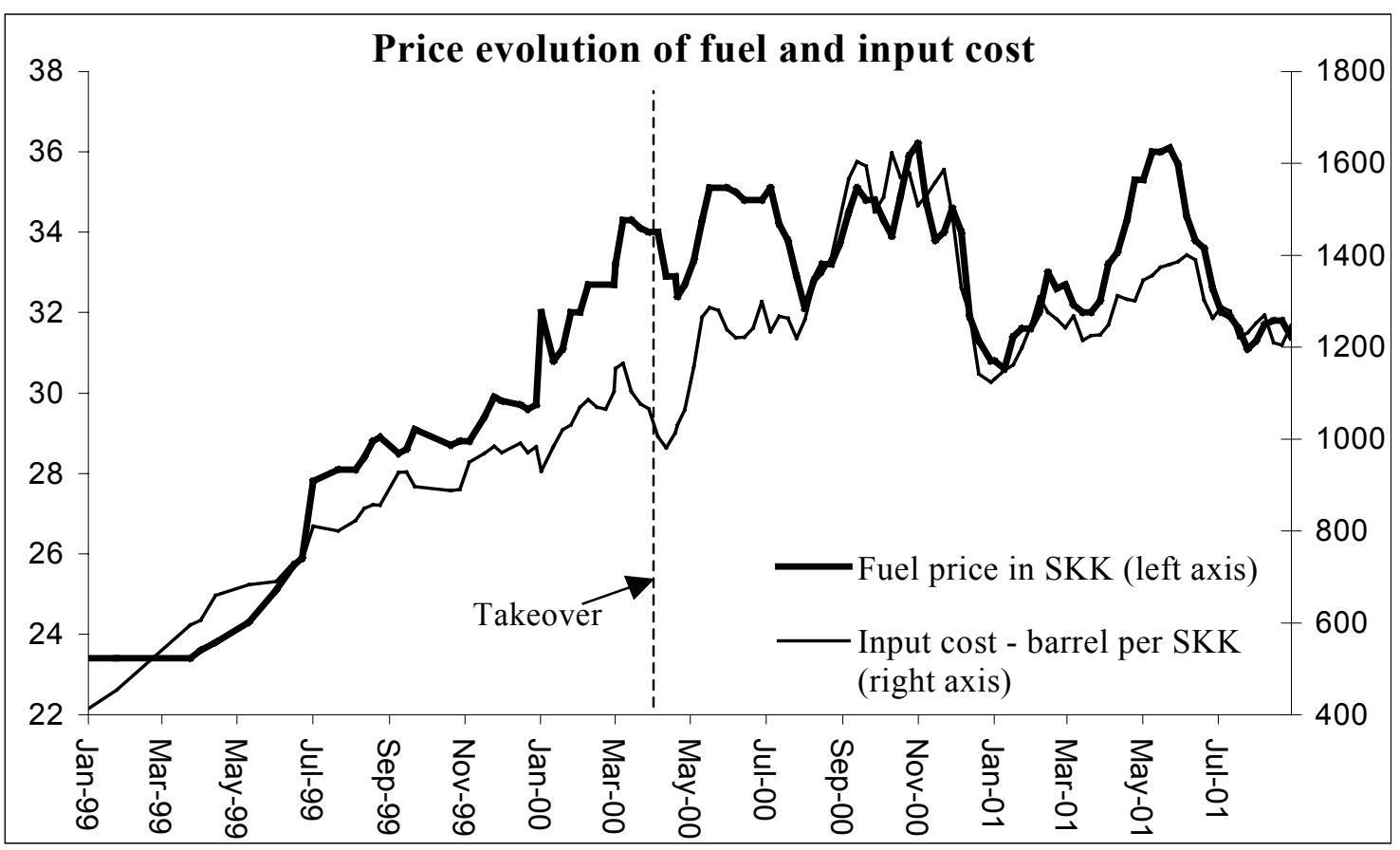

